\title{
Pengaruh Perceived Social Support terhadap Psychological Distress pada Remaja X di Masa Pandemi COVID-19
}

\author{
Putri Nurul Aliyah *, Sulisworo Kusdiyati \\ Prodi Psikologi, Fakultas Psikologi, Universitas Islam Bandung, Indonesia. \\ * putrinalyh@gmail.com, sulisworokusdiyati@gmail.com
}

\begin{abstract}
An increase in psychological distress is one of the side effects caused by physical distancing. Social support has the greatest influence on psychological distress. Perceived social support is a form of support that does not have to involve real support and is more subjective in nature, depending on how individuals perceive the support provided by others. A person's perception of the existence of support from social support sources is negatively related to psychological distress. This study aims to determine the effect of perceived social support from family, friends, and significant others on psychological distress in high school adolescents in West Java during the COVID-19 pandemic. This research uses causality method with quantitative approach. Measurements were made using measuring instruments that have been adapted to the Indonesian context, namely the Kessler Psychological Distress Scale (K10) and the Multidimensional Scale of Perceived Social Support (MSPSS). The research sample was 680 high school teenagers in West Java who were selected through convenience sampling. The data analysis technique used linear regression test. The result of this study is that the family dimension significantly has the greatest influence $(\beta=-.593 ; p<.05$; $\mathrm{R} 2=.126)$. Women had a significantly higher score than men on psychological distress $(\mathrm{M}=28.21$; $\mathrm{SD}=7.937)$. Statistically, perceived social support had a significant effect on psychological distress $(\beta=-.252$; $\mathrm{p}<.05)$. The coefficient of determination for $\mathrm{R} 2$ is $7.5 \%$.
\end{abstract}

Keywords: COVID-19 Pandemic, Perceived Social Support, Psychological Distress, Adolescent.

\begin{abstract}
Abstrak. Peningkatan distres psikologis salah satu efek samping yang ditimbulkan akibat adanya physical distancing. Dukungan sosial memiliki pengaruh terbesar terhadap distres psikologis. Dukungan sosial yang dirasakan (perceived social support) merupakan bentuk dukungan yang tidak harus melibatkan adanya dukungan secara nyata dan lebih bersifat subjektif, tergantung bagaimana individu mempersepsikan dukungan yang diberikan oleh orang lain. Persepsi seseorang mengenai adanya dukungan dari sumber dukungan sosial berhubungan negatif dengan psychological distress. Penelitian ini bertujuan untuk mengetahui pengaruh perceived social support dari family, friends, dan significant other terhadap psychological distress pada remaja SMA di Jawa Barat pada masa pandemi COVID-19. Penelitian ini menggunakan metode kausalitas dengan pendekatan kuantitatif. Pengukuran dilakukan dengan menggunakan alat ukur yang telah di adaptasi ke dalam konteks Indonesia, yaitu Kessler Psychological Distress Scale (K10) dan Multidimensional Scale of Perceived Social Support (MSPSS). Sampel penelitian berjumlah 680 remaja SMA di Jawa Barat yang dipilih melalui convenience sampling. Teknik analisis data menggunakan uji regresi linear. Hasil penelitian ini adalah dimensi family secara signifikan memiliki pengaruh paling besar $(\beta=-.593 ; p<.05 ; \mathrm{R} 2=.126)$. Perempuan memiliki skor yang secara signifikan lebih tinggi daripada laki-laki pada psychological distress $(M=28.21 ; S D=7.937)$. Secara statistik perceived social support berpengaruh signifikan terhadap psychological distress $(\beta=-.252 ; \mathrm{p}<.05)$. Koefisien determinasi untuk R2 sebesar 7.5\%
\end{abstract}

Kata Kunci: Pandemi COVID-19, Dukungan Sosial yang dirasakan, Distres Psikologis, Remaja. 


\section{A. Pendahuluan}

Terhitung sejak akhir tahun 2019 sampai dengan saat ini, seluruh negara di berbagai belahan dunia sedang dilanda wabah penyakit yang diakibatkan oleh penyebaran virus, yang saat ini dikenal dengan sebutan COVID-19. Sebagai bentuk respon terhadap bahaya dari penyebaran virus corona, pemerintah memberlakukan adanya physical distancing yang bertujuan untuk mengurangi berbagai risiko agar penularan virus tidak semakin menyebar luas.

Physical distancing pada remaja berpotensi menimbulkan masalah kesehatan mental, dengan laporan yang menunjukkan tingginya tingkat gangguan stress pasca trauma, depresi, serta adanya upaya bunuh diri (Hall-Lande et al., 2007; Jiang et al., 2020; Li et al., 2020). Penelitian yang dilakukan oleh Nearchou et al. (2020) dan Zhou et al. (2020) membuktikan bahwa physical distancing akibat COVID-19 berdampak pada kesehatan mental remaja yang berusia 12 hingga 18 tahun, diketahui bahwa kelompok usia tersebut berisiko tinggi mengalami distres psikologis (Nearchou et al., 2020; Zhou, 2020).

Survei yang dilakukan oleh IPK Indonesia dan Fakultas Psikologi Universitas Airlangga menunjukkan bahwa dampak physical distancing menimbulkan distres psikologis pada remaja di seluruh jenjang pendidikan, namun yang lebih utama berpengaruh pada siswa SMA (Annisa, 2020; IPK, 2020). Didukung dengan data yang diperoleh dari media massa, selama pandemi ini terdapat beberapa kasus remaja di Indonesia yang mengalami depresi dan beberapa diantaranya berujung pada tindakan bunuh diri. Dapat diketahui bahwa kasus bunuh diri tersebut lebih banyak ditemukan pada siswa SMA (Abdul, 2020; Callistasia, 2021; Sutrisno, 2021).

Berdasarkan fenomena yang ada, diketahui bahwa siswa SMA merupakan yang paling sering merasakan dampak dari adanya physical distancing. Menurut Santrock (2011), masa sekolah menengah adalah masa dimana seluruh hal mengalami perubahan atau transisi, baik dari segi perubahan sosial, kehidupan di sekolah yang berbeda, kehidupan dengan keluarga, serta juga kehidupan individual. Seluruh perubahan yang terjadi rentan untuk membuat individu yang berada di tingkat pendidikan tersebut merasa tertekan (Ananda \& Apsari, 2020). Remaja yang duduk di tingkat pendidikan SMA memiliki rentang usia 15-18 tahun, sehingga masa SMA ini lebih sering kita kenal dengan istilah remaja.

Menurut Papalia (2007) pada masa ini, sedang mengalami masa transisi dan berada pada tahap membangun identitas diri, yang membuat remaja menjadi sangat rentan terhadap gejolak emosional, adanya perasaan cemas, dan sering mengalami perasaan negatif lainnya (Kristofora \& Hendriati, 2021). Salah satu cara utama dalam proses membentuk identitas diri yaitu dengan memiliki kesempatan dalam melakukan interaksi sosial dengan teman, komunitas sosial, atau berbagai kegiatan kelompok lainnya. Tugas perkembangan remaja pada periode ini salah satunya adalah berelasi dan berorientasi dengan teman (Every-Palmer et al., 2020).

Penelitian telah menunjukkan bahwa depresi pada masa remaja dapat memberikan dampak yang merugikan pada kesehatan psikologis, pada fungsi sosial dan kehidupan seharihari individu, serta produktivitas dalam kehidupan di masa dewasa. Sehingga, physical distancing akibat adanya pandemi dapat meningkatkan munculnya distres psikologis yang lebih berat (Ling et al., 2019; Thelin et al., 2017).

Distres adalah pengalaman emosional yang tidak menyenangkan yang disebabkan oleh berbagai faktor dan dapat diwujudkan sebagai adanya ketegangan, ketakutan, kecemasan, dan ketidakstabilan psikologis. Menurut Mirowsky dan Ross (2003) depresi dan kecemasan secara kolektif disebut distres psikologis (Dharma et al., 2020; Mirowsky \& Ross, 2017).

Kerentanan terhadap distres psikologis selama pandemi COVID-19 dapat disebabkan oleh berbagai faktor, salah satunya karena kurangnya dukungan sosial (Brooks et al., 2020; C. Zhang et al., 2020). Dukungan sosial merupakan salah satu faktor situasional yang memiliki pengaruh terbesar dalam mempengaruhi distres psikologis. Dukungan sosial dapat berperan sebagai faktor pelindung pada kesehatan mental dan fisik, sehingga mampu mengurangi distres psikologis yang dialami individu (Feng et al., 2013; Szkody et al., 2020).

Penginterpretasian dukungan sosial dapat terjadi karena proses persepsi. Seringkali lingkungan individu telah memberikan dukungan yang suportif, tetapi dukungan tersebut tidak sesuai dengan kebutuhan individu, sehingga tidak dipersepsikan sebagai sesuatu yang 
memadai atau mendukung dalam mengatasi masalah individu (Ningrum \& Sukmayanti, 2013). Hal tersebut bergantung pada dukungan sosial yang dirasakan individu atau dikenal dengan istilah perceived social support. Taylor et al. (2004) mengemukakan bahwa sebagai sumber daya, dukungan sosial terkadang lebih bermanfaat dalam persepsinya daripada dalam penggunaannya (Taylor et al., 2004).

Perceived social support mengacu pada ketersediaan dan kecukupan koneksi sosial yang dirasakan dan adanya pemikiran individu bahwa dukungan tersebut tersedia jika diperlukan (Dewayani et al., 2011; Eagle et al., 2019). Menurut Cohen dan Wills (1985) persepsi seseorang mengenai adanya dukungan dan sumber daya dari anggota dalam jaringan sosialnya lebih berhubungan negatif dengan psychological distress (Hawryluck et al., 2004; Maryanti \& Herani, 2020; Taylor, 2018). Hal ini terbukti pada penelitian yang dilakukan oleh Grey et al. (2020) dan Xu et al. (2020) yang menunjukkan bahwa perceived social support yang tinggi terbukti memiliki risiko depresi yang lebih rendah selama pandemi COVID-19 (Grey et al., 2020; Xu et al., 2020).

Menurut Zimet et al. (1988) perceived social support memiliki tiga dimensi yang menjadi sumber dukungan sosial, yaitu family, friends, dan significant other. Sumber dukungan dapat berubah-ubah tergantung pada kebutuhan individu dan situasi yang dialami individu. Diketahui bahwa hasil yang berbeda pada perilaku individu tergantung pada sumber dukungan yang dirasakan (Paykani et al., 2020).

Bukti menunjukkan bahwa peringkat yang lebih tinggi dari perceived social support yang bersumber dari keluarga saat pandemi ini dilaporkan terkait dengan tingkat depresi yang lebih rendah. Sedangkan, teman dan orang penting lainnya dianggap memiliki kapasitas yang lebih rendah untuk memvalidasi pengalaman emosional individu selama pandemi, karena mereka kemungkinan mengalami permasalahan emosional yang serupa, sehingga kurang mampu dalam meredakan stres yang dialami oleh individu (Liu et al., 2020).

Hal tersebut dapat dibuktikan pada penelitian yang dilakukan oleh Mariani et al. (2020) dan Xu et al. (2020) yang menunjukkan bahwa dukungan sosial dari keluarga lebih berpengaruh dalam pengurangan masalah kecemasan dan depresi selama pandemi COVID-19. Diketahui bahwa hubungan keluarga memiliki peran penting sebagai penyangga stres (Mariani et al., 2020; Xu et al., 2020).

Berdasarkan latar belakang yang telah diuraikan, maka perumusan masalah dalam penelitian ini sebagai berikut, (1) bagaimana gambaran perceived social support dari family, friends, dan significant other pada remaja SMA di masa pandemi COVID-19, (2) bagaimana gambaran psychological distress pada remaja SMA di masa pandemi COVID-19, (3) seberapa besar pengaruh perceived social support terhadap psychological distress pada remaja SMA di masa pandemi COVID-19.

\section{B. Metodologi Penelitian}

Menurut Zimet, Dahlem, Zimet dan Farley (1988) perceived social support merupakan cara individu mengartikan ketersediaan sumber dukungan yang berasal dari orang terdekat yaitu keluarga (family), teman (friends) dan orang penting lainnya (significant other) yang dapat meningkatkan kemampuan individu dalam menghadapi kesulitan yang dialami termasuk gejala dan peristiwa stres.

Menurut Kessler (2002), psychological distress merupakan suatu ketidakstabilan kondisi yang berdampak pada masalah ketidaknyamanan emosi, kognisi, perilaku, dan perasaan individu seperti kecemasan, suasana hati depresi, kepenatan atau kelelahan, dorongan untuk selalu bergerak tanpa istirahat, dan ketidakberhargaan diri individu, dimana gejalagejala tersebut didasarkan pada kriteria distres psikologis (depresi dan kecemasan) yang tercantum di dalam DSM-V.

Penelitian ini menggunakan pendekatan kuantitatif dengan metode kausalitas yang bertujuan untuk menemukan ada tidaknya pengaruh di antara dua variabel, serta menetapkan bahwa nilai dari variabel independen memiliki satu efek signifikan terhadap variabel dependen (Silalahi, 2015). Pemilihan sampel dalam penelitian ini dilakukan dengan menggunakan 
rancangan online survei melalui google-from dan teknik convenience sampling. Penelitian ini dilakukan terhadap siswa SMA yang tersebar di Jawa Barat $(N=680)$ yang didapatkan melalui convenience sampling.

Penelitian ini menggunakan dua alat ukur yang telah diadaptasi pada konteks remaja Indonesia. Multidimensional Scale of Perceived Social Support (MSPSS) telah di adaptasi oleh Laksmita et al. (2020), alat ukur ini digunakan untuk mengukur struktur tiga faktor dari skala (Family, Friends, dan Significant Other), yang terdiri dari 12 item dengan menggunakan skala likert tujuh pilihan alternatif jawaban dari (1) sangat sangat tidak setuju sampai (7) sangat sangat setuju. Hasil Confirmatory Factor Analysis (CFA) menunjukkan bahwa struktur tiga faktor yang dihipotesiskan menunjukkan kecocokan yang sangat baik dengan data, karena semua parameter $\left(\frac{x 2}{d f}<5\right.$, GFI $>.90$, CFI $>.90$, TLI $>.90$, dan SRMR $\left.<.08\right)$ sesuai dengan kriteria yang direkomendasikan dengan hasil sangat baik. Cronbach's Alpha yang dihasilkan menunjukkan konsistensi internal yang tinggi $(a>.7)$.

Untuk Kessler Psychological Distress Scale (K10) telah di adaptasi oleh Tran et al. (2019), alat ukur ini digunakan untuk mengukur tingkat distres psikologis, yang terdiri dari 10 item yang mengevaluasi seberapa sering responden mengalami gejala kecemasan depresif seperti, adanya perasaan gugup, sedih, gelisah, putus asa, dan tidak berharga yang berlangsung selama 30 hari terakhir. Setiap item diskalakan dari mulai (0) tidak ada waktu sampai dengan (4) sepanjang waktu. Analisis dalam adaptasi alat ukur ini menghasilkan koefisien Cronbach's Alpha yaitu sebesar .89, dengan nilai optimal cut-off $\geq 18$ dan AUC .79 yang dikategorikan sebagai akurasi sedang, sehingga skala ini memiliki konsistensi internal dan kemampuan diskriminan yang baik untuk mendeteksi gangguan depresi atau kecemasan.

Analisis data dalam penelitian ini menggunakan analisis statistik deskriptif, yaitu analisis regresi linear sederhana.

\section{Hasil dan Pembahasan}

Tabel 1. Besaran jumlah dimensi perceived social support

\begin{tabular}{lcc}
\hline \multicolumn{1}{c}{ Dimensi } & $\boldsymbol{n}$ & \% \\
\hline Family & 339 & 41.2 \\
Frineds & 157 & 19.1 \\
Significant & 184 & 22.4 \\
$\begin{array}{l}\text { Other } \\
\quad \text { Total }\end{array}$ & 680 & 100 \\
\hline
\end{tabular}

Tabel 2. Besaran jumlah dimensi perceived social support

\begin{tabular}{lrcccc}
\hline & Coefficient & $\boldsymbol{t}$ & $\boldsymbol{F}$ & Sig. & $\boldsymbol{R}^{2}$ \\
\hline Constant & 39.126 & -9.876 & 97.531 & $.000^{*}$ & .126 \\
Family & -.593 & & & & \\
Constant & 31.120 & -3.974 & 15.797 & $.000^{*}$ & .023 \\
Friends & -.226 & & & & \\
Constant & 33.538 & -5.520 & 30.473 & $.000 *$ & .043 \\
Other & -.327 & & & & \\
\hline Dther
\end{tabular}

Dependen Variabel: Psychological Distress

Predictors (Constant): Perceived Social Support, Family, Frineds, Significant Other

*Signifikan pada $\mathrm{p}<.05$

Berdasarkan data yang telah diperoleh, hasil menunjukkan bahwa remaja SMA di Jawa Barat pada masa pandemi COVID-19, lebih banyak merasakan dukungan sosial yang bersumber dari keluarga dan orang penting lainnya (orang spesial) seperti sahabat ataupun pasangan, daripada bersumber dari teman. Dukungan keluarga memiliki pengaruh yang lebih besar dalam menurunkan distres psikologis yang dialami remaja $\left(\beta=-.593 ; p<.05 ; \mathrm{R}^{2}=.126\right)$. 
Beberapa penelitian yang dilakukan pada masa pandemi COVID-19 menunjukkan bahwa sumber dukungan sosial yang paling berpengaruh dalam menurunkan distres psikologis individu adalah yang bersumber dari keluarga (Mariani et al., 2020; Xu et al., 2020). Teman dan orang penting lainnya dianggap memiliki kapasitas yang lebih rendah untuk memvalidasi pengalaman emosional individu selama pandemi, karena mereka kemungkinan mengalami permasalahan emosional yang serupa, sehingga kurang mampu dalam meredakan stres yang dialami oleh individu (Liu et al., 2020).

Penelitian menunjukkan bahwa dalam hal pengurungan di rumah, orang tua seringkali menjadi yang terdekat dan sumber daya terbaik bagi anak-anak untuk mencari bantuan. Komunikasi yang erat dan terbuka dengan anak-anak adalah kunci untuk mengidentifikasi masalah fisik dan psikologis apa pun dan untuk menghibur anak-anak dalam isolasi yang berkepanjangan (Wang et al., 2020). Tidak adanya komunikasi yang melibatkan emosi antara orang tua dan anaknya dapat membuat anak-anak merasa cemas, tidak didengarkan, dan ini akan mengakibatkan anak-anak merasa harus mengatasi rasa kekhawatirannya sendiri, sehingga beresiko untuk mengalami atau memperparah distres psikologis (Dalton et al., 2020).

Tabel 3. Data deskriptif psychological distress

\begin{tabular}{|c|c|c|c|c|}
\hline $\begin{array}{c}\text { Jenis } \\
\text { Kelamin }\end{array}$ & $N$ & Mean & $S D$ & Sig. \\
\hline Laki-laki & 233 & 24.21 & 7.572 & $.000^{*}$ \\
\hline Perempuan & 447 & 28.21 & 7.937 & $.000^{*}$ \\
\hline
\end{tabular}

Berdasarkan data yang diperoleh pada tabel 3, menunjukkan bahwa secara signifikan remaja perempuan mengalami distres psikologis yang lebih tinggi $(M=24.21)$ dibandingkan dengan remaja laki-laki $(M=28.21)$. Beberapa penelitian menunjukkan bahwa, jenis kelamin perempuan memang dikaitkan dengan adanya distres psikologis yang lebih tinggi berupa kecemasan, depresi, dan stres (Grey et al., 2020; Mazza et al., 2020; Petzold et al., 2020). Temuan ini juga sejalan dengan hasil penelitian sebelumnya oleh Wang et al. (2020) dan Qiu et al. (2020) yang secara konsisten menemukan hubungan antara jenis kelamin perempuan dengan adanya peningkatan tekanan psikologis. Penemuan ini dapat dikaitkan dengan bukti dalam literatur internasional bahwa wanita cenderung lebih rentan mengalami stres dan mengembangkan gejala stress pasca trauma (Mazza et al., 2020; Petzold et al., 2020).

Perempuan lebih mungkin mengalami depresi dibandingkan dengan laki-laki, karena perempuan lebih mementingkan peran dukungan sosial dalam mengatasi stres. Beberapa penelitian menunjukkan bahwa wanita memiliki jaringan sosial yang lebih besar dibandingkan laki-laki. Oleh karena itu, dukungan sosial memainkan peran yang lebih penting dalam mengurangi risiko depresi berat di kalangan wanita (M. Zhang et al., 2018). Penelitian lain yang dilakukan oleh Rahman et al. (2020) mengenai tekanan psikologis pada populasi di Australia, menyatakan bahwa wanita memiliki distres dan ketakutan yang lebih tinggi terhadap COVID-19, karena dapat berperan sebagai salah satu prediktor yang konsisten untuk mengalami tekanan psikologis. Alasan lain yang dikemukakan di dalam penelitian ini adalah, karena perempuan secara tidak proporsional berbagi persentase peran pengasuhan yang lebih besar, serta lebih sering berfungsi sebagai pengasuh utama, dalam rumah tangga. Sehingga, dengan beban yang lebih besar, kemungkinan akan lebih menonjolkan kecemasan dan stres dalam situasi pandemi (Rahman et al., 2020). 
Tabel 4. Hasil uji analisis regresi linear

\begin{tabular}{lrrrrr}
\hline & Coefficient & $\boldsymbol{t}$ & $\boldsymbol{F}$ & Sig. & $\boldsymbol{R}^{2}$ \\
\hline Constant & 34.231 & -7.433 & 55.246 & $.000^{*}$ & .075 \\
Perceived & -.252 & & & & \\
Social & & & & & \\
support & & & & &
\end{tabular}

\footnotetext{
a. $\quad$ Dependen Variabel: Psychological Distress

b. Predictors (Constant): Perceived Social Support, Family, Frineds, Significant Other *Signifikan pada $p<.05$
}

Berdasarkan pengujian yang dilakukan pada tabel 1, dapat diketahui bahwa perceived social support $(\beta=-.252 ; p<.05)$ berkontribusi negatif dan signifikan terhadap psychological distress. Artinya, remaja yang memiliki perceived social support tinggi, akan mampu menghasilkan psychological distress yang lebih rendah.

Hasil penelitian ini sejalan dengan penelitian yang dilakukan oleh Grey et al. (2020) yang bertujuan untuk memeriksa peran perceived social support dengan berbagai hasil kesehatan psikologis di antara individu yang menjalani physical distancing selama COVID19. Hasil menunjukkan bahwa individu yang mengalami isolasi diri memiliki tingkat depresi, lekas marah dan kesepian yang jauh lebih tinggi dibandingkan dengan mereka yang tidak. Risiko peningkatan gejala depresi adalah $63 \%$ lebih rendah pada individu yang melaporkan tingkat perceived social support yang lebih tinggi. Sehingga, secara signifikan perceived social support yang tinggi terkait dengan adanya penurunan risiko depresi atau masalah psikologis lainnya selama pandemi COVID-19 (Grey et al., 2020).

Berdasarkan pengujian pada dimensi perceived social support, dapat diketahui bahwa seluruh dimensi perceived social support berpengaruh negatif terhadap psychological distress. Diketahui bahwa dimensi yang yang paling berpengaruh dalam menurunkan distres psikologis adalah family. Family support dapat menjadi yang terpenting karena berada pada lingkungan terdekat bagi individu (Wang et al., 2020).

Penelitian menunjukkan bahwa peringkat yang lebih tinggi dari dukungan sosial yang dirasakan dari keluarga dilaporkan terkait dengan tingkat depresi yang lebih rendah. Sedangkan, teman dan orang penting lainnya dianggap memiliki kapasitas yang lebih rendah untuk memvalidasi pengalaman emosional individu selama pandemi, karena mereka kemungkinan mengalami permasalahan emosional yang serupa, sehingga kurang mampu dalam meredakan stres yang dialami oleh individu (Liu et al., 2020). Beberapa penelitian yang dilakukan pada masa pandemi COVID-19 menunjukkan bahwa sumber dukungan sosial yang paling berpengaruh dalam menurunkan distres psikologis individu adalah yang bersumber dari keluarga.

Penelitian yang dilakukan oleh Mariani et al. (2020) terhadap penduduk Italia yang melakukan karantina di awal pandemi COVID-19 menyatakan bahwa dukungan sosial khususnya dukungan keluarga terkait dengan lebih sedikit kecemasan dan depresi selama pandemi COVID-19. Dukungan keluarga menjadi penting karena di Italia orang telah dipaksa untuk tinggal di rumah selama beberapa bulan, sehingga lebih sering menghabiskan banyak waktu dengan anggota keluarga. Oleh karena itu, penelitian ini menegaskan bahwa aspek terpenting yang dapat menyangga konsekuensi negatif dan mengurangi depresi dan kecemasan selama pandemi COVID-19 adalah dukungan yang bersumber dari keluarga. Hubungan keluarga dapat bertindak sebagai penyangga stres jika memadai dan mendukung, atau sebagai faktor risiko depresi, jika dianggap tidak memadai dan tidak mendukung (Mariani et al., 2020). Oleh karena itu, perlu diketahui secara lebih lanjut mengenai pemaknaan individu mengenai kualitas dari kecukupan dan ketersediaan dukungan sosial yang diterima oleh individu.

Penelitian lain yang dilakukan oleh Xu et al. (2020) menunjukkan hasil bahwa pada tahap pra-pandemi dan penurunan COVID-19, dukungan sosial yang dirasakan dari significant other dan friends dapat berperan dalam menyangga efek merugikan dari sifat kesepian 
terhadap kecemasan kronis dan kecemasan COVID-19. Namun, hasil terbalik pada tahap puncak COVID-19, sehingga hanya dukungan sosial yang dirasakan dari family yang dapat menyangga efek merugikan dari sifat kesepian hingga kecemasan COVID-19. Xu et al. (2020) memperkirakan bahwa dalam kehidupan sehari-hari dan pada saat stresor akut umumnya telah berlalu, dukungan sosial dari significant other dan friends cenderung melindungi orang yang kesepian dari kecemasan, sedangkan sumber dukungan sosial ini melemah ketika menghadapi stresor yang lebih mengancam jiwa. Sebaliknya, hubungan antar anggota keluarga telah menjadi hubungan terpenting bagi kebanyakan orang pada tahap puncak COVID-19 ketika hampir semua orang dikurung di rumah. Studi di masa depan diperlukan untuk memeriksa lebih lanjut peran sistem keluarga, yaitu dengan melihat bagaimana hubungan orang tua-anak, hubungan perkawinan, dan lingkungan keluarga dalam melindungi individu dari kecemasan (Xu et al., 2020).

Penelitian menunjukkan bahwa dalam hal pengurungan di rumah, orang tua seringkali menjadi yang terdekat dan sumber daya terbaik bagi anak-anak untuk mencari bantuan. Komunikasi yang erat dan terbuka dengan anak-anak adalah kunci untuk mengidentifikasi masalah fisik dan psikologis apa pun dan untuk menghibur anak-anak dalam isolasi yang berkepanjangan (Wang et al., 2020). Tidak adanya komunikasi yang melibatkan emosi antara orang tua dan anaknya dapat membuat anak-anak merasa cemas, tidak didengarkan, dan ini akan mengakibatkan anak-anak merasa harus mengatasi rasa kekhawatirannya sendiri, sehingga beresiko untuk mengalami atau memperparah distres psikologis (Dalton et al., 2020).

\section{Kesimpulan}

Berdasarkan pembahasan dalam penelitian ini, peneliti menyimpulkan beberapa hasil penelitian sebagai berikut:

1. Sebagian besar remaja SMA di Jawa Barat lebih banyak merasakan dukungan sosial yang bersumber dari keluarga dalam menurunkan distres psikologis di masa pandemi COVID-19. Dukungan sosial yang dirasakan dari keluarga memiliki pengaruh yang lebih besar dalam menurunkan distres psikologis yang dialami remaja SMA di Jawa Barat pada masa pandemi COVID-19.

2. Penelitian ini memberikan gambaran bahwa, remaja yang berejenis kelamin perempuan memiliki distres psikologis yang lebih tinggi dibandingkan laki-laki.

3. Penelitian ini menunjukkan bahwa, perceived social support berpengaruh negatif terhadap psychological distress. Artinya, apabila dukungan sosial yang dirasakan remaja SMA tinggi, maka akan mampu menurunkan distres psikologis yang dialami inidividu pada masa pandemi COVID-19.

\section{Acknowledge}

Penulis mengucapkan terima kasih kepada Ibu Sulisworo Kusdiyati, Dra., M.Si., Psikolog. selaku dosen pembimbing yang senantiasa memberikan masukan, bimbingan, dan juga arahan selama pelaksanaan penelitian. Terima kasih kepada seluruh responden yang telah berkenan untuk meluangkan waktu dalam pengisian kuesioner penelitian.

\section{Daftar Pustaka}

[1] Abdul, H. (2020, October 20). Siswi SMA Bunuh Diri karena Beban Tugas Daring, Dinas Pendidikan Evaluasi Sistem Belajar Online. Kompas.Com. https://regional.kompas.com/read/2020/10/20/15592941/siswi-sma-bunuh-diri-karenabeban-tugas-daring-dinas-pendidikan-evaluasi

[2] Ananda, S. S. D., \& Apsari, N. C. (2020). Mengatasi stres pada remaja saat pandemi COVID-19 dengan teknik self-talk. Prosiding Penelitian Dan Pengabdian Kepada Masyarakat, 7(2), 248-256. https://doi.org/10.24198/jppm.v7i2.29050

[3] Annisa, R. (2020, November 11). Menjawab Kebutuhan Psikologis Remaja di Masa Pandemi. UNAIR News. http://news.unair.ac.id/2020/11/11/menjawab-kebutuhan- 
psikologis-remaja-di-masa-pandemi/

[4] Brooks, Webster, R. K., Smith, L. E., Woodland, L., Wessely, S., Greenberg, N., \& Rubin, G. J. (2020). The psychological impact of quarantine and how to reduce it: rapid review of the evidence. The Lancet, 395(10227), 912-920. https://doi.org/10.1016/S0140$6736(20) 30460-8$

[5] Callistasia, W. (2021, February 18). Covid-19: "Stres, mudah marah, hingga dugaan bunuh diri”, persoalan mental murid selama sekolah dari rumah. BBC News Indonesia. https://www.bbc.com/indonesia/indonesia-55992502

[6] Dalton, L., Rapa, E., \& Stein, A. (2020). Protecting the psychological health of children through effective communication about COVID-19. The Lancet Child and Adolescent Health, 4(5), 346-347. https://doi.org/10.1016/S2352-4642(20)30097-3

[7] Dewayani, A., Sukarlan, A. D., \& Turnip, S. S. (2011). Perceived Peer Social Support Dan Psychological Distress Mahasiswa Universitas Indonesia. Makara Human Behavior Studies in Asia, 15(2), 86. https://doi.org/10.7454/mssh.v15i2.1303

[8] Dharma, I. G. M., Yuliadi, I., \& Setyowati, R. (2020). Hubungan antara Adversity Quotient dengan Distres Psikologis pada Mahasiswa Program Studi Kedokteran Universitas Sebelas Maret Surakarta. Philanthropy Journal of Psychology, 4(2), 172-191.

[9] Eagle, D. E., Hybels, C. F., \& Proeschold-Bell, R. J. (2019). Perceived social support, received social support, and depression among clergy. Journal of Social and Personal Relationships, 36(7), 2055-2073. https://doi.org/10.1177/0265407518776134

[10] Every-Palmer, S., Jenkins, M., Gendall, P., Hoek, J., Beaglehole, B., Bell, C., Williman, J., Rapsey, C., \& Stanley, J. (2020). Psychological distress, anxiety, family violence, suicidality, and wellbeing in New Zealand during the COVID-19 lockdown: A crosssectional study. PLoS ONE, $15(11 \quad$ November), 1-19. https://doi.org/10.1371/journal.pone.0241658

[11] Feng, D., Ji, L., \& Xu, L. (2013). The influence of social support, lifestyle and functional disability on psychological distress in rural China: Structural equation modelling. Australian Journal of Rural Health, 21(1), 13-19. https://doi.org/10.1111/ajr.12009

[12] Grey, I., Arora, T., Thomas, J., Saneh, A., Tohme, P., \& Abi-habib, R. (2020). Since January 2020 Elsevier has created a COVID-19 resource centre with free information in English and Mandarin on the novel coronavirus COVID- 19. The COVID-19 resource centre is hosted on Elsevier Connect, the company' s public news and information. Psychiatry Research, 293(January).

[13] Hall-Lande, J., Eisenberg, M., Christenson, S., \& Neumark-Sztainer, D. (2007). Social isolation, psychological health, and protective factors in adolescence. Adolescence, 42(166), 265-286.

[14] Hawryluck, L., Gold, W. L., Robinson, S., Pogorski, S., Galea, S., \& Styra, R. (2004). SARS control and psychological effects of quarantine, Toronto, Canada. Emerging Infectious Diseases, 10(7), 1206-1212. https://doi.org/10.3201/eid1007.030703

[15] IPK. (2020). Kiprah Psikologi Klinis untuk Indonesia di Masa Pandemi. 1-30. https://data.ipkindonesia.or.id/data-satgas-

covid19/Kiprah_Psikologi_Klinis_untuk_Indonesia_di_Masa_Pandemi.pdf

[16] Jiang, H., Yu, W., Lin, D., \& Macnamara, B. N. (2020). Resilience of Adolescents, Though Weakened During Pandemic-Related Quarantine, Serves as a Protective Process Against Depression and Sleep Problems. https://doi.org/10.31234/osf.io/u86zj

[17] Kristofora, E., \& Hendriati, A. (2021). The Role of the Quality of Perceived Social Support in the Emotion Regulation Strategies of Adolescents in Jakarta. ANIMA Indonesian Psychological Journal, 36(1), 69-89. https://doi.org/10.24123/aipj.v36i1.1573

[18] Li, S., Wang, Y., Xue, J., Zhao, N., \& Zhu, T. (2020). The impact of covid-19 epidemic declaration on psychological consequences: A study on active weibo users. Int $\mathbf{J}$ Environ Res Public Health [revista en Internet] 2020 [acceso 13 de abril de 202021]; 30(3): 201-205. International Journal of Environmental Research and Public Health, 
17(6). 02032.pdf

https://www.ncbi.nlm.nih.gov/pmc/articles/PMC7143846/pdf/ijerph-17-

[19] Ling, Y., Liu, C., Scott Huebner, E., Zeng, Y., Zhao, N., \& Li, Z. (2019). A study on classification features of depressive symptoms in adolescents. Journal of Mental Health, O(0), 1-8. https://doi.org/10.1080/09638237.2019.1677865

[20] Liu, C. H., Zhang, E., Wong, G. T. F., Hyun, S., \& Hahm, H. "Chris." (2020). Factors associated with depression, anxiety, and PTSD symptomatology during the COVID-19 pandemic: Clinical implications for U.S. young adult mental health. Psychiatry Research, 290(June). https://doi.org/10.1016/j.psychres.2020.113172

[21] Mariani, R., Renzi, A., Di Trani, M., Trabucchi, G., Danskin, K., \& Tambelli, R. (2020). The Impact of Coping Strategies and Perceived Family Support on Depressive and Anxious Symptomatology During the Coronavirus Pandemic (COVID-19) Lockdown. Frontiers in Psychiatry, 11(November), 1-9. https://doi.org/10.3389/fpsyt.2020.587724

[22] Maryanti, W., \& Herani, I. (2020). Perceived Social Support dan Psychological Distress Pada Penderita Penyakit Kanker. Jurnal Psikologi, 16(1), 91-100. https://doi.org/http://dx.doi.org/10.24014/ jp.v14i2.9155

[23] Mazza, C., Ricci, E., Biondi, S., Colasanti, M., Ferracuti, S., Napoli, C., \& Roma, P. (2020). A nationwide survey of psychological distress among italian people during the covid-19 pandemic: Immediate psychological responses and associated factors. International Journal of Environmental Research and Public Health [revista en Internet] 2020 [acceso. International Journal of Environmental Research and Public Health, 17, 1-14. https://www.ncbi.nlm.nih.gov/pmc/articles/PMC7246819/pdf/ijerph-1703165.pdf

[24] Mirowsky, J., \& Ross, C. E. (2017). Social Causes of Psychological Distress Second Edition.

[25] Nearchou, F., Hennessy, E., Flinn, C., Niland, R., \& Subramaniam, S. S. (2020). Exploring the impact of covid-19 on mental health outcomes in children and adolescents: A systematic review. International Journal of Environmental Research and Public Health, 17(22), 1-19. https://doi.org/10.3390/ijerph17228479

[26] Ningrum, M. J. S., \& Sukmayanti, L. M. K. (2013). Persepsi Dukungan Sosial dan Kemampuan Komunikasi Interpersonal pada Pasien Tuberkulosis Paru di Denpasar. Jurnal Psikologi Udayana, 41-51. https://ojs.unud.ac.id/index.php/psikologi/article/view/25125/16338

[27] Paykani, T., Zimet, G. D., Esmaeili, R., Khajedaluee, A. R., \& Khajedaluee, M. (2020). Perceived social support and compliance with stay-at-home orders during the COVID19 outbreak: evidence from Iran. BMC Public Health, 20(1), 1-9. https://doi.org/10.1186/s12889-020-09759-2

[28] Petzold, M. B., Bendau, A., Plag, J., Pyrkosch, L., Mascarell Maricic, L., Betzler, F., Rogoll, J., Große, J., \& Ströhle, A. (2020). Risk, resilience, psychological distress, and anxiety at the beginning of the COVID-19 pandemic in Germany. Brain and Behavior, 10(9), 1-10. https://doi.org/10.1002/brb3.1745

[29] Rahman, M. A., Hoque, N., Alif, S. M., Salehin, M., Islam, S. M. S., Banik, B., Sharif, A., Nazim, N. B., Sultana, F., \& Cross, W. (2020). Factors associated with psychological distress, fear and coping strategies during the COVID-19 pandemic in Australia. Globalization and Health, 16(1), 1-15. https://doi.org/10.1186/s12992-020-00624-w

[30] Silalahi, U. (2015). Metode Penelitian Sosial Kuantitatif. Bandung: PT. Refika Aditama.

[31] Sutrisno, D. (2021, June 1). No Title. IDN Times Jabar. https://jabar.idntimes.com/news/jabar/debbie-sutrisno/tragis-siswa-sman-16-bandungdiduga-bunuh-diri-loncat-dari-lantai/2

[32] Szkody, E., Stearns, M., Stanhope, L., \& McKinney, C. (2020). Stress-Buffering Role of Social Support during COVID-19. Family Process, $x(\mathrm{x})$, 1-14. https://doi.org/10.1111/famp.12618 
[33] Taylor, S. (2018). Health Psychology (10th ed.). McGraw-Hill Education.

[34] Taylor, Sherman, D. K., Kim, H. S., Jarcho, J., Takagi, K., \& Dunagan, M. S. (2004). Culture and Social Support: Who Seeks It and Why?. Journal of Personality and Social Psychology, 87(3), 354-362. https://doi.org/10.1037/0022-3514.87.3.354

[35] Thelin, C., Mikkelsen, B., Laier, G., Turgut, L., Henriksen, B., Olsen, L. R., Larsen, J. K., \& Arnfred, S. (2017). Danish translation and validation of Kessler's 10-item psychological distress scale-K10. Nordic Journal of Psychiatry, 71(6), 411-416. https://doi.org/10.1080/08039488.2017.1312517

[36] Wang, G., Zhang, Y., Zhao, J., Zhang, J., \& Jiang, F. (2020). Mitigate the effects of home confinement on children during the COVID-19 outbreak. The Lancet, 395(10228), 945947. https://doi.org/10.1016/S0140-6736(20)30547-X

[37] Xu, J., Ou, J., Luo, S., Wang, Z., Chang, E., Novak, C., Shen, J., Zheng, S., \& Wang, Y. (2020). Perceived Social Support Protects Lonely People Against COVID-19 Anxiety: A Three-Wave Longitudinal Study in China. Frontiers in Psychology, 11(November), 1-12. https://doi.org/10.3389/fpsyg.2020.566965

[38] Zhang, C., Ye, M., Fu, Y., Yang, M., Luo, F., Yuan, J., \& Tao, Q. (2020). The psychological impact of the COVID-19 pandemic on teenagers in China. Journal of Adolescent Health, 67, 747-755. https://doi.org/10.1016/j.jadohealth.2020.08.026

[39] Zhang, M., Zhang, J., Zhang, F., Zhang, L., \& Feng, D. (2018). Prevalence of psychological distress and the effects of resilience and perceived social support among Chinese college students: Does gender make a difference? Psychiatry Research, 267, 409-413. https://doi.org/10.1016/j.psychres.2018.06.038

[40] Zhou, X. (2020). Managing Psychological Distress in Children and Adolescents Following the COVID-19 Epidemic: A Cooperative Approach. Psychological Trauma: Theory, Research, Practice, and Policy, 12, 76-78. https://doi.org/10.1037/tra0000754 